\title{
Pengolahan Buah Naga pada Kelompok Tani Nagari Simpang Sugiran, Kecamatan Guguk, Kabupaten Lima Puluh Kota
}

\author{
Mimi Harni, Fidela Violalita, Ermiati, Irwan Roza, Yenni Muchrida, Tety Desrita Handayani, \\ Henny Fitri Yanti, dan Agustina \\ Jurusan Teknologi Pertanian, Politeknik Pertanian Negeri Payakumbuh, Sumatera Barat 26271, Indonesia \\ E-mail: mimiharni2009@gmail.com
}

Keywords: diversification, dragon fruit, Simpang Sugiran Village

Kata Kunci:

buah naga,

diversifikasi, Nagari Simpang Sugiran

\begin{abstract}
Red dragon fruit is one of the agricultural commodities in Simpang Sugiran Village. Dragon fruit has many functions and properties for health. Based on monitoring in the field, farmers do not have the knowledge and skills in processing dragon fruit into various processed dragon fruit products to increase their selling value. In addition, the price of dragon fruit and farmer acceptance continues to decline while the number of farmers cultivating is increasing. The purpose of this activity was to increase community knowledge and skills in processing dragon fruit, and business management to increase the added value of dragon fruit cultivation. The results of community service activities indicated that the diversification of dragon fruit processing is one of the most effective ways to increase community income in the Simpang Sugiran village. Dragon fruit can be processed into various processed products using simple technology and can be done as a home industry. This community service activity can motivate and encourage the entrepreneurial spirit of the Farmer Group of Simpang Sugiran, Guguak Sub District, Lima Puluh Kota, West Sumatra.
\end{abstract}

\footnotetext{
ABSTRAK

Buah naga merah merupakan salah satu komoditi pertanian di Nagari Simpang Sugiran. Buah naga memiliki banyak fungsi dan khasiat untuk kesehatan. Berdasarkan hasil survei di lapangan, petani belum memiliki pengetahuan dan keterampilan dalam melakukan pengolahan buah naga menjadi berbagai produk olahan buah naga untuk meningkatkan nilai jualnya. Selain itu harga buah naga dan penerimaan petani yang terus menurun sedangkan jumlah petani yang membudidayakan semakin meningkat. Tujuan kegiatan ini adalah meningkatkan pengetahuan dan keterampilan masyarakat dalam mengolahan buah naga dan manajemen usaha dalam rangka meningkatkan nilai tambah dari budidaya buah naga. Hasil kegiatan pengabdian masyarakat menunjukkan bahwa diversifikasi pengolahan buah naga merupakan salah satu cara yang sangat efektif untuk meningkatkan pendapatan masyarakat di Nagari Simpang Sugiran. Buah naga dapat diolah menjadi berbagai produk olahan dengan menggunakan teknologi yang sederhana, dan dapat dilakukan pada industri rumah tangga. Kegiatan pengabdian masyarakat ini mampu menjadi motivasi dan mendorong jiwa kewirausahaan Kelompok Tani Nagari Simpang Sugiran Kecamatan Guguak, Kabupaten Lima Puluh Kota, Sumatera Barat.
} 


\section{PENDAHULUAN}

Buah naga merah merupakan salah satu komoditi pertanian di Nagari Simpang Sugiran. Buah naga memiliki banyak fungsi dan khasiat untuk kesehatan. Dari segi nilai gizi, setiap $100 \mathrm{~g}$ buah naga mengandung 82,5-83 g air, 0,21-0,61 g lemak, 0,15-0,22 g protein, 0,7-0,9 g serat, 0,005-0,01 mg karoten, 6,3-8,8 mg kalsium, 30,2-31,6 mg posfor, 0,55-0,65 mg besi, 13- 18 briks kadar gula, 11,5 g karbohidrat, 60,4 mg magnesium serta vitamin B1, B2 dan vitamin C. Komposisi gizi buah naga dipercaya berkhasiat dapat menyeimbangkan gula darah, mencegah kanker usus, melindungi kesehatan mulut, menurunkan kolesterol, menguatkan fungsi ginjal dan tulang, mencegah pendarahan, sehingga secara keseluruhan meningkatkan daya tahan tubuh (Basri, dkk., 2013).

Penggemar buah naga di pasar domestik berangsur-angsur meningkat. Hal ini bisa dilihat dari semakin membanjirnya buah naga di supermarket maupun di pasar tradisional di beberapa kota di Indonesia. Ketersediaan buah naga kadang langka dan kadang banyak. Ketika buah naga ketersediaannya melimpah, maka harga jual menjadi rendah. Permasalahan lainnya selain itu karena terbatasnya daya simpan buah naga yang mengakibatkan buah mudah busuk dan terbuang. Hal-hal ini memicu kerugian untuk petani. Petani buah naga di Nagari Simpang Sugiran juga mengalami kondisi demikian, sehingga harus ada suatu upaya untuk memperpanjang masa simpan buah, seperti dengan cara mengolahnya menjadi produk turunan.

Berdasarkan kualitas kandungannya buah naga sangat baik untuk dikembangkan sebagai makanan kesehatan. Berdasarkan pantauan di lapangan, petani belum memiliki pengetahuan dan keterampilan dalam melakukan pengolahan buah naga menjadi berbagai produk olahan untuk meningkatkan nilai jualnya. Selain itu harga buah naga dan penerimaan petani yang terus menurun sedangkan jumlah petani yang membudidayakan semakin meningkat. Pengolahan buah naga menjadi berbagai produk seperti kerupuk, dodol, selai, jelly kering, donat dan stick, merupakan upaya yang dilakukan untuk mengatasi masalah Kelompok Tani Buah Naga Nagari Simpang Sugiran. Prospek inilah yang membuat buah naga dapat dijadikan sebagai sebuah ide cemerlang untuk membuka lahan bisnis baru bagi mereka yang berjiwa pengusaha. Selain itu juga dapat membuka lapangan pekerjaan baru untuk mengurangi pengangguran di Nagari Simpang Sugiran.

Sesuai dengan uraian latar belakang dan perumusan masalah yang telah dikemukakan di atas, maka pengabdian kepada masyarakat yang dilaksanakan ini memiliki beberapa tujuan, antara lain: 1) meningkatkan pengetahuan dan keterampilan masyarakat dalam mengolah hasil buah naga dan manajemen usaha dalam rangka meningkatkan nilai tambah dari budidaya buah naga, 2) diharapkan mampu menyerap hasil budidaya buah naga yang ada di daerah tersebut, 3) membuka peluang usaha pengolahan buah naga menjadi produk yang dapat dipasarkan dan sekaligus dapat dijadikan salah satu produk unggulan Nagari Simpang Sugiran, dan 4) guna membekali kelompok tani tentang wawasan untuk menjadi wirausahawan dengan mendirikan industri kecil dan menengah yang mampu menyerap tenaga kerja di pedesaan.

\section{METODE}

Kegiatan dilakukan di Jorong Boncah Nagari Simpang Sugiran, Kecamatan Guguak, Kabupaten Lima Puluh Kota. Kegiatan penyuluhan, pelatihan, dan demonstrasi pengolahan buah naga menjadi produk pangan diikuti oleh beberapa orang sebagai perwakilan dari anggota Kelompok Tani Buah Naga Sejahtera, Jorong Boncah, Nagari Simpang Sugiran. Metode yang digunakan dalam kegiatan pengabdian masyarakat ini adalah metode ceramah, praktek, dan diskusi. Metode ceramah digunakan untuk menjelaskan materi tentang diversifikasi olahan buah 
naga. Metode praktek digunakan untuk praktek membuat olahan produk berbasis buah naga, mulai dari pengolahan dan pengemasan. Teknik pengemasan untuk meningkatkan mutu dan harga jual dengan packing yang berkualitas. Metode diskusi dilakukan setelah penyuluhan selesai dengan tujuan untuk mengetahui respons peserta. Evaluasi peningkatan pengetahuan dan keterampilan dari mitra dilakukan melalui tanya jawab. Monitoring dan evaluasi dilakukan pada saat program berlangsung.

Bahan utama yang disiapkan dalam kegiatan pengabdian ini adalah buah naga merah. Sedangkan, bahan penunjangnya, antara lain gula pasir, tepung terigu, tepung beras ketan, tepung tapioka, agar-agar, baking powder, air mineral (air bersih), garam, asam sitrat dan keju. Peralatan yang dibutuhkan adalah pisau, blender, kompor, panci, pengaduk, timbangan, kemasan plastik, mesin Ampia, pengukus dan wajan.

Tahapan pelaksanaan kegiatan sebagai berikut:

- Tahap persiapan

Tahap persiapan yaitu sosialisasi. Sosialisasi merupakan tahap awal pelaksanaan kegiatan. Tahapan ini bertujuaan untuk menginformasikan tujuan, target, dan luaran program pengabdian ke kelompok tani sehingga kegiatan ini mendapat dukungan sosial dan dapat terlaksana dengan baik dan lancar. Tahap sosialisasi ini dilakukan dengan metode diskusi secara langsung dengan Kelompok Tani Buah Naga Sejahtera Jorong Boncah Negari Simpang Sugiran.

- Tahap pelaksanaan

Teknis pelaksanaan pengabdian yaitu: a) penyampaian materi penyuluhan tentang diversifikasi produk olahan buah naga, b) Demonstrasi pengolahan buah naga, dan c) pendampingan teknis proses produksi, pengemasan, pemasaran dan kewirausahaan.

- Tahap monitoring dan evaluasi

Monitoring dan evaluasi dalam kegiatan pengabdian ini dilakukan pada setiap tahapan kegiatan (on-going) dan evaluasi keseluruhan kegiatan atau evaluasi akhir. Adapun hal-hal yang menjadi fokus dalam pelaksanaan evaluasi diantaranya tingkat partisipasi anggota kelompok tani pada setiap kegiatan dan peningkatan pengetahuan serta keterampilan anggota kelompok dan evaluasi terhadap proses produksi dan produk yang dihasilkan, pengemasan dan pemasaran.

\section{HASIL DAN PEMBAHASAN}

\section{Tahap Persiapan}

Kegiatan pelatihan diversifikasi pengolahan buah naga diawali dengan sosialisasi kepada Kelompok Tani Buah Naga Sejahtera Jorong Boncah Nagari Simpang Sugiran yang menjadi sasaran. Kegiatan ini dihadiri oleh Direktur BUMNAG Simpang Sugiran, Wali Nagari Simpang Sugiran, Perwakilan Ibu PKK Nagari Simpang Sugiran, dan anggota Kelompok Tani Buah Naga Sejahtera Jorong Bocah Nagari Simpang Sugiran. Kegiatan sosialisasi ini bertujuan untuk menginformasikan kepada kelompok tani mengenai rencana yang akan dilaksanakan oleh tim pengabdi. Tahap sosialisasi ini dilakukan dengan metode diskusi secara langsung dengan Kelompok Tani Buah Naga Sejahtera Jorong Bocah Negari Simpang Sugiran.

Hasil dari kegiatan ini menunjukkan bahwa Kelompok Tani Buah Naga Sejahtera Jorong Boncah Nagari Simpang Sugiran cukup antusias dan mengapresiasi kegiatan yang dilaksanakan. Hal ini terlihat dengan banyaknya informasi yang disampaikan oleh anggota kelompok tani dalam wawancara yang dilakukan oleh tim pengabdi menyangkut kondisi terakhir hasil pertanian buah naga. Setelah melakukan sosialisasi dan wawancara dengan anggota kelompok 
tani, selanjutnya tim pengabdi melakukan penyusunan makalah aneka proses pengolahan buah naga.

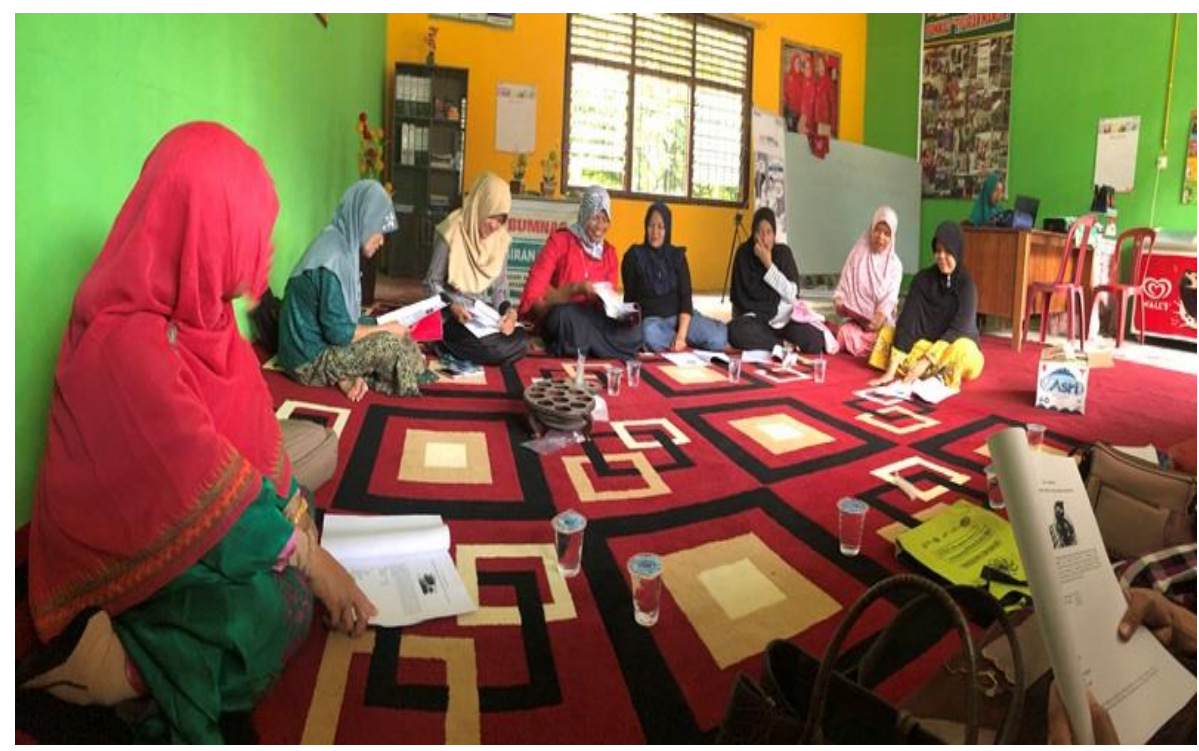

Gambar 1. Sosialisasi program pengabdian oleh Tim dari Program Studi Teknologi Pangan

\section{Tahap Pelaksanaan}

Pelaksanaan kegiatan dilakukan beberapa kali pertemuan dengan mengambil tempat di Kantor BUMNAG Simpang Sugiran. Pelaksanaan dimulai dengan penyampaian materi penyuluhan tentang diversifikasi produk olahan buah naga, dilanjutkan dengan demonstrasi pengolahan buah naga. Kegiatan penyuluhan diversifikasi produk olahan buah naga bertujuan untuk meningkatkan pengetahuan sekaligus keterampilan anggota kelompok tani, sehingga dari itu diharapkan dapat meningkatkan pendapatan masyarakat Nagari Simpang Sugiran. Setelah kegiatan penyuluhan, kemudian dilanjutkan dengan kegiatan praktek atau demonstrasi.

Kegiatan praktek dilaksanakan dengan membagi peserta dalam kelompok kecil berdasarkan alat yang tersedia. Sebelum praktek, terlebih dahulu dijelaskan tentang bahan utama dan pendukung, alat yang diperlukan, dan cara pembuatannya. Selanjutnya masing-masing peserta diharuskan berperan aktif dalam setiap langkah atau proses pembuatan olahan buah naga. Hasil olahan yang telah matang disuguhi kepada semua peserta untuk dicicipi rasanya. Sebagian produk dikemas, dan dilakukan evaluasi tentang praktek hari tersebut.

Pelaksanaan penyuluhan dan demonstrasi pengolahan kerupuk buah naga (Gambar 2), pengolahan selai buah naga (Gambar 3), pengolahan jelly kering buah naga (Gambar 4), pengolahan cheese stick buah naga (Gambar 5), pengolahan dodol (Gambar 6), pengolahan donat buah naga (Gambar 7), penyuluhan tentang pemasaran (Gambar 8) dan kewirausahaan (Gambar 9) sudah berhasil dilaksanakan dengan baik sesuai dengan rencana kegiatan. Anggota kelompok tani sangat antusias mengikuti dan menerima penyuluhan dan demonstrasi yang dilakukan oleh tim kegiatan pengabdian. Dalam kegiatan tersebut, 25 orang ibu-ibu anggota kelompok tani telah terampil dalam pengolahan kerupuk buah naga. 

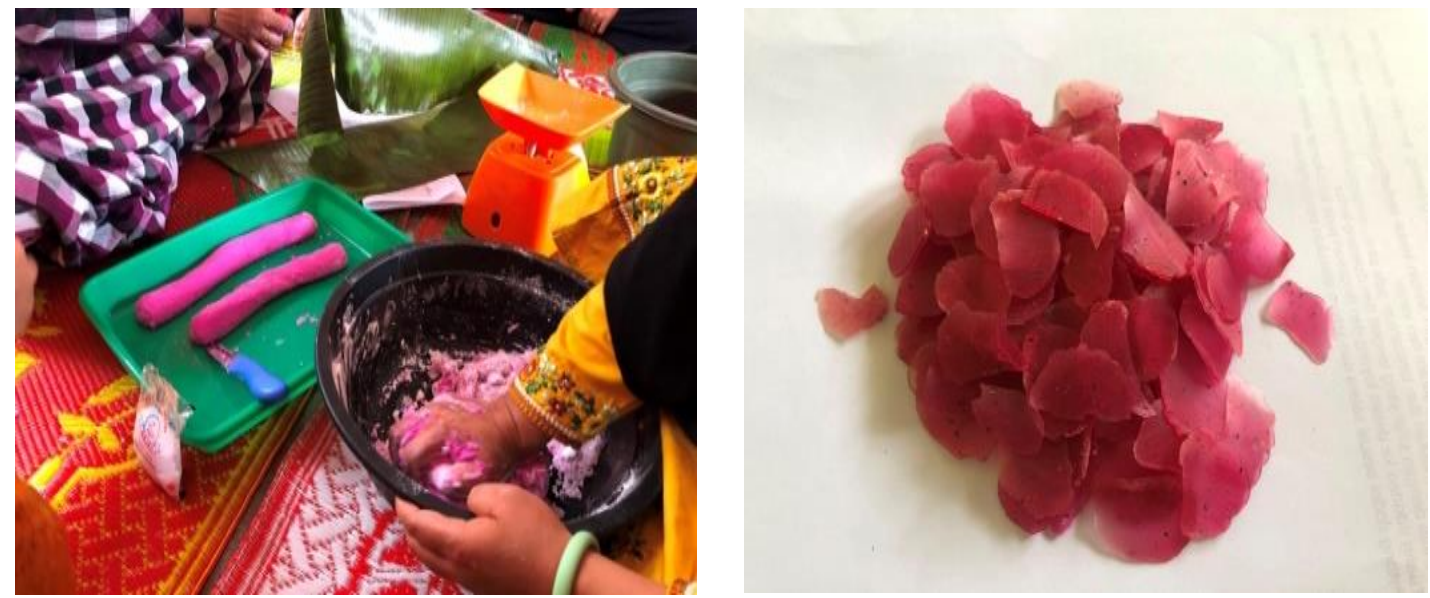

Gambar 2. Penyuluhan dan demonstrasi pengolahan kerupuk buah naga
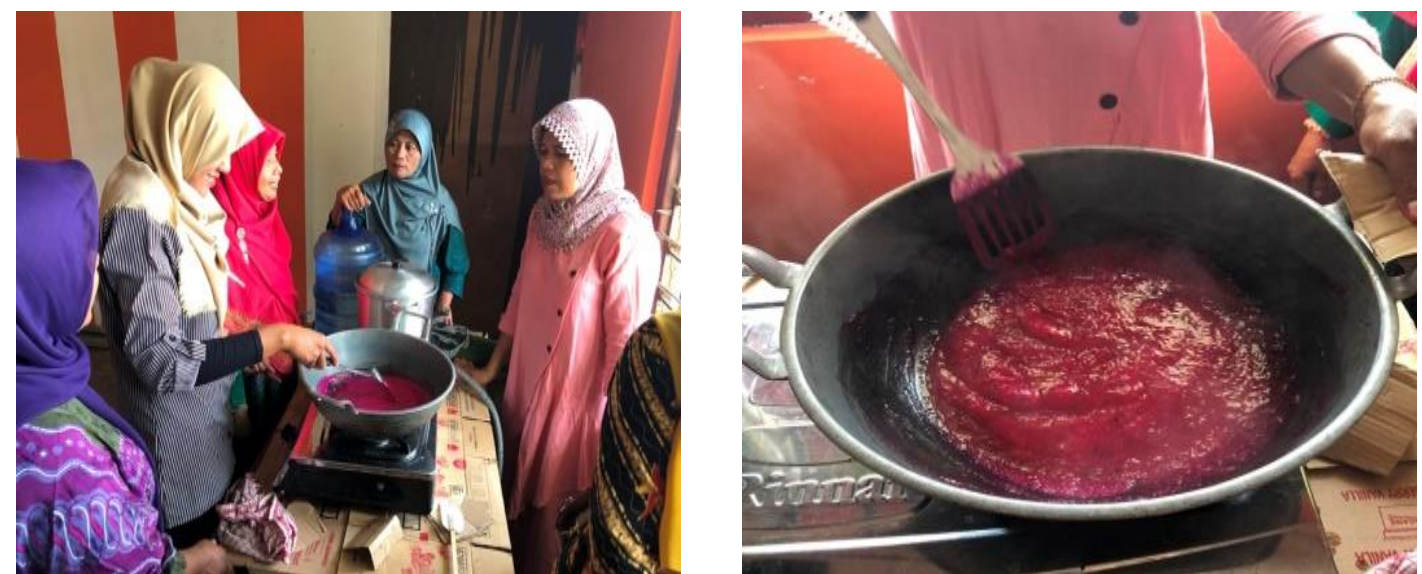

Gambar 3. Penyuluhan dan demonstrasi pengolahan selai buah naga
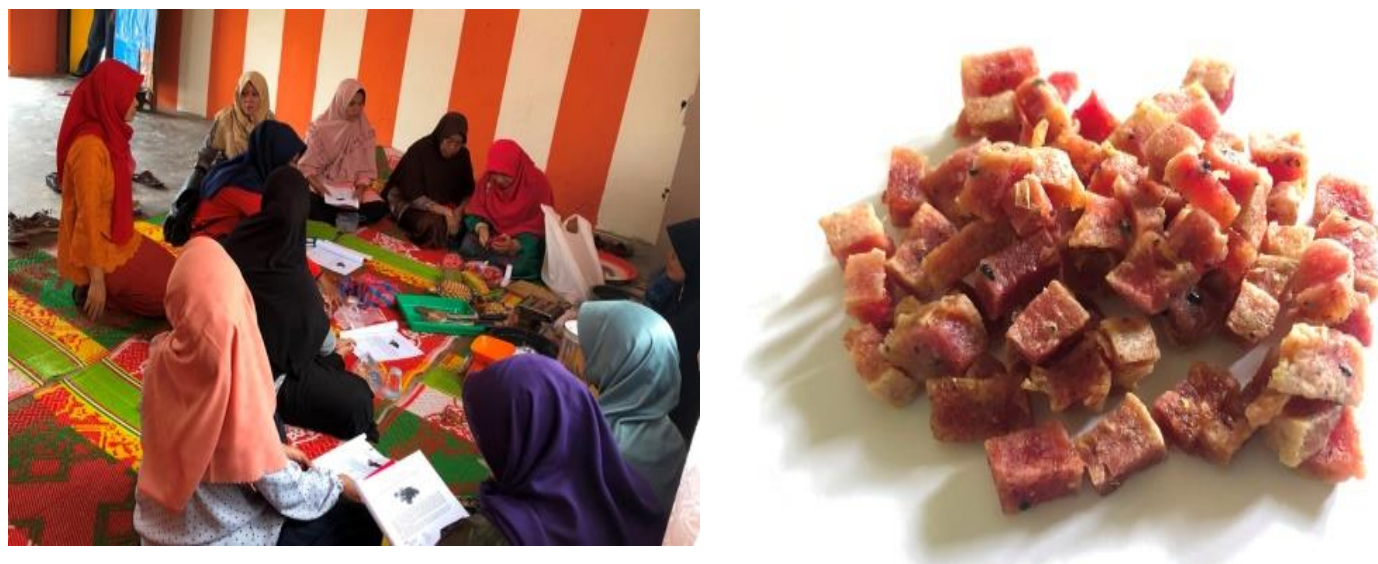

Gambar 4. Penyuluhan dan demonstrasi pengolahan jelly kering buah naga 

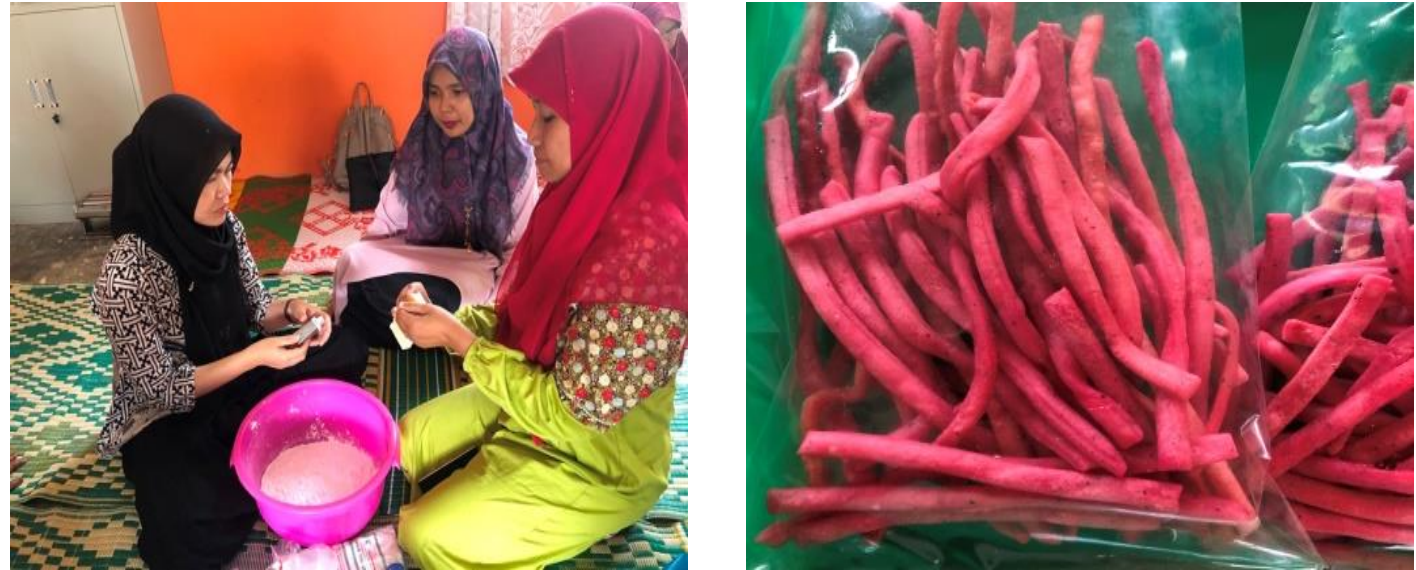

Gambar 5. Penyuluhan dan demonstrasi pengolahan cheese stick buah naga
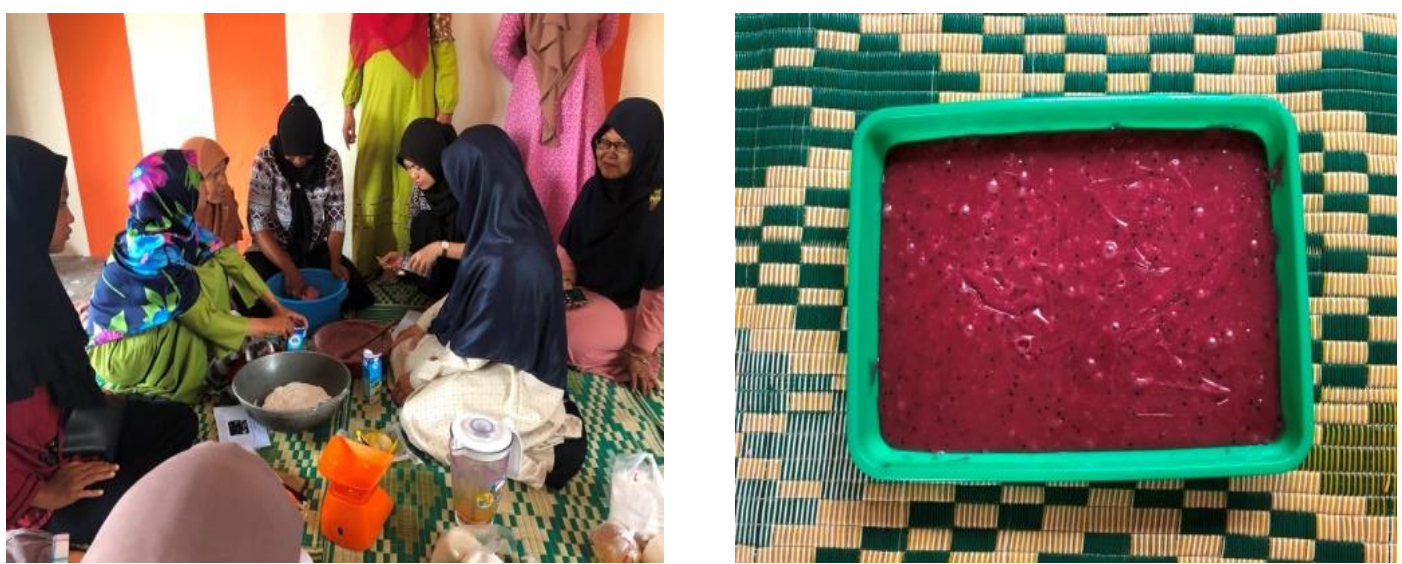

Gambar 6. Penyuluhan dan demonstrasi pengolahan dodol buah naga
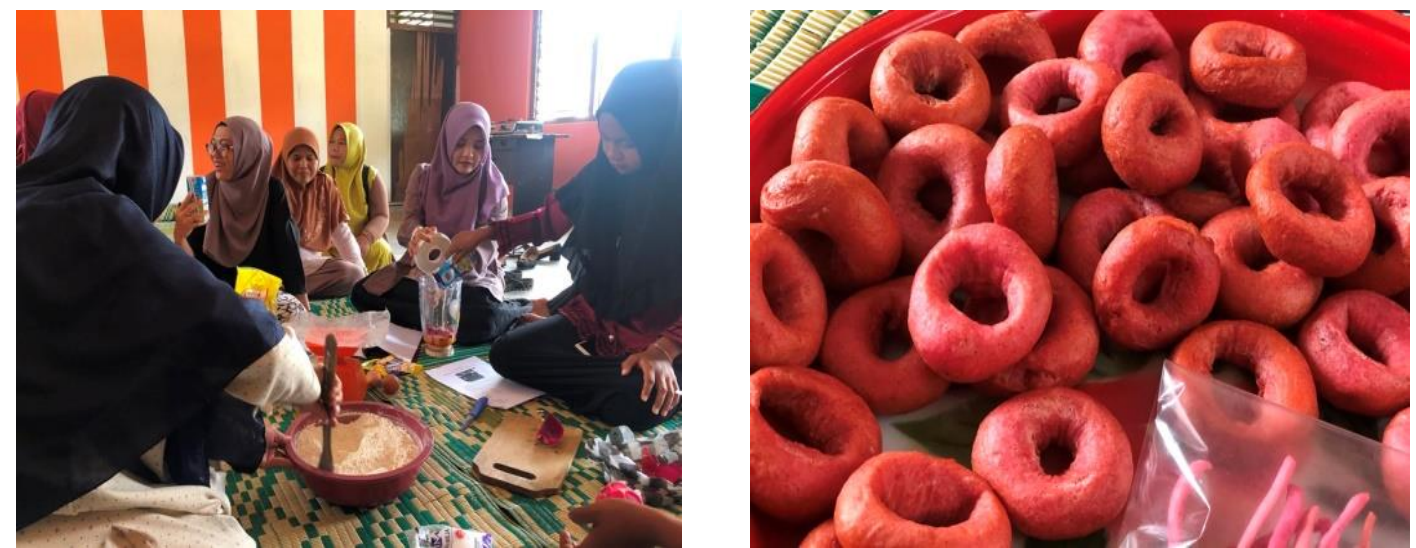

Gambar 7. Penyuluhan dan demonstrasi pengolahan donat buah naga 


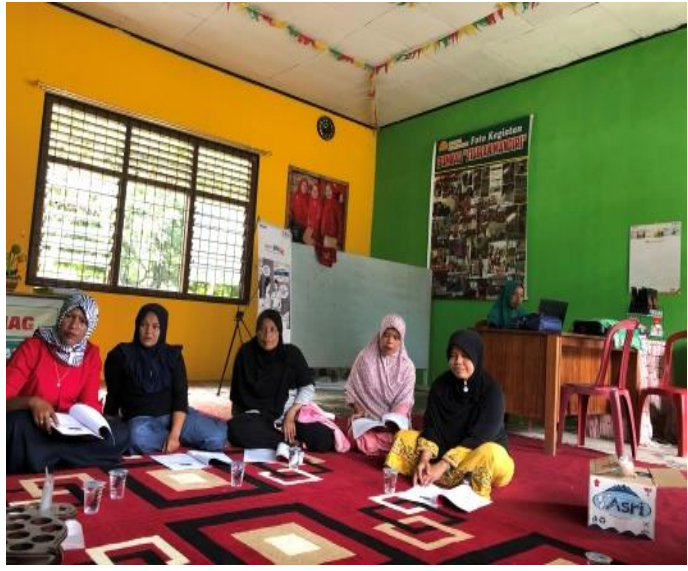

Gambar 8. Penyuluhan tentang Pemasaran

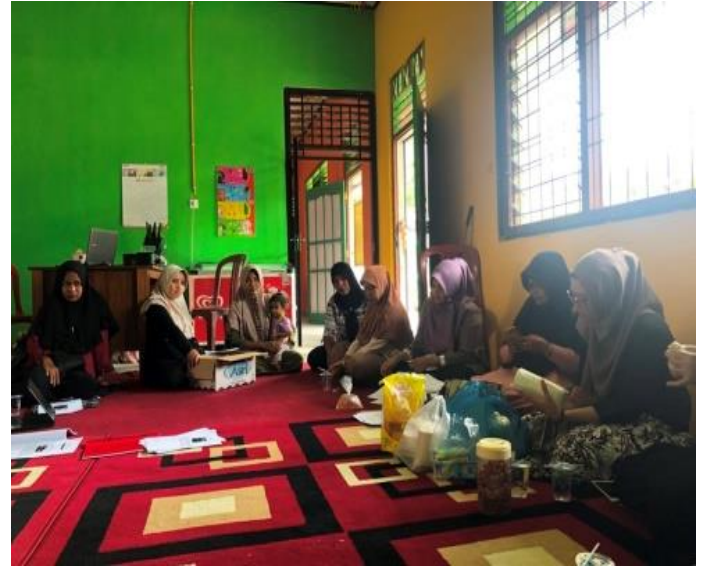

Gambar 9. Penyuluhan tentang Kewirausahaan

Kerusakan bahan pangan dapat disebabkan oleh dua hal, yaitu kerusakan oleh sifat alamiah dari produk yang berlangsung secara spontan dan kerusakan karena pengaruh lingkungan. Oleh karena itu, diperlukan pengemas untuk membatasi bahan pangan dengan lingkungan untuk mencegah atau menunda proses kerusakan sehingga produk mempunyai daya tahan lebih lama untuk dikonsumsi. Menurut Syarief (1990) salah satu fungsi kemasan adalah melindungi makanan dari kerusakan fisik, perubahan kadar air dan penyinaran. Materi penyuluhan tentang pengemasan ditambahkan disela waktu penyuluhan dan demonstrasi pengolahan buah naga. Selain itu kelompok tani buah naga sejahtera jorong boncah didampingi untuk mampu melakukan pengemasan produk. Hasilnya, anggota kelompok tani dapat mengikuti pelatihan pengemasan dengan baik dan mampu mengemas produk dengan sangat rapi.

Pengemasan adalah kegiatan merancang dan memproduksi wadah atau bungkus sebagai sebuah produk (Kotler \& Keller, 2009). Biasanya fungsi utama dari kemasan adalah untuk menjaga produk, namun sekarang kemasan menjadi faktor yang cukup penting sebagai alat pemasaran (Rangkuti, 2010). Laku tidaknya suatu produk selain dinilai dari mutu produk (rasa, penampilan produk) juga ditentukan oleh usaha promosi yang dilakukan misalnya dari penampilan kemasan. Untuk meningkatkan nilai produk, maka aneka olahan buah naga dikemas dalam keamasan yang lebih higienis dan dan dibuat semenarik mungkin.

Strategi pemasaran aneka olahan buah naga menjadi materi penutup (Gambar 8), sehingga peserta mendapatkan gambaran tentang pemasaran olahan buah naga. Strategi pemasaran adalah logika pemasaran dimana unit bisnis berharap untuk menciptakan nilai dan memperoleh keuntungan dari hubungannya dengan konsumen (Kotler \& Amstrong, 2008). Pada kesempatan ini, tim pengabdian menyampaikan materi penyuluhan strategi pemasaran secara konvensional dan juga secara digital. Selain strategi pemasaran anggota kelompok tani juga dibekali dengan materi penyuluhan tentang kewirausahaan (Gambar 9), pentingnya usaha mandiri atau kewirausahaan, kiat-kiat usaha dan memanfaatkan peluang yang ada, serta guna meningkatkan nilai tambah produk.

\section{Tahap monitoring dan evaluasi}

Menurut Peraturan Pemerintah Nomor 39 Tahun 2006, disebutkan bahwa monitoring merupakan suatu kegiatan mengamati secara seksama suatu keadaan atau kondisi, termasuk juga perilaku atau kegiatan tertentu, dengan tujuan agar semua data masukan atau informasi yang diperoleh dari hasil pengamatan tersebut dapat menjadi landasan dalam mengambil keputusan tindakan selanjutnya yang diperlukan. Monitoring dan evaluasi yang telah dilakukan dalam pelaksanaan kegiatan penyuluhan dan demonstrasi ini adalah tingkat partisipasi anggota kelompok tani pada setiap kegiatan, tingkat pengetahuan anggota kelompok tani, dan tingkat 
keterampilan anggota kelompok tani. Evaluasi terhadap tingkat partisipasi ini dilakukan pada setiap rangkaian kegiatan dengan cara memonitoring dan mengevaluasi jumlah kehadiran anggota kelompok (peserta pelatihan).

Evaluasi ini dilakukan pada tahap awal (penyuluhan) dan akhir dari kegiatan pelatihan (demonstrasi). Hal ini untuk memastikan tingkat pengetahuan kelompok mitra sebelum dan setelah diadakannya kegiatan penyuluhan. Dalam proses evaluasi menggunakan metode wawancara. Dari hasil kegiatan bersama kelompok mitra diperoleh hasil yang positif. Dari hasil evaluasi didapatkan bahwa partisipasi anggota sangat tinggi dan ini terbukti dari tingkat kehadiran yang direncanakan adalah 25 orang anggota untuk kelompok tani. Di samping itu antusias anggota dalam mengikuti kegiatan juga terbilang sangat tinggi di mana peserta aktif mengikuti seluruh rangkaian kegiatan hingga kegiatan berakhir.

\section{KESIMPULAN}

Kegiatan pengabdian untuk pemberdayaan masyarakat dalam membuat produk olahan buah naga membawa dampak positif. Selain untuk meningkatkan nilai ekonomi dari buah naga juga memberi manfaat bagi anggota kelompok tani, yaitu meningkatnya keterampilan dan pengetahuan anggota kelompok tani terkait pembuatan olahan buah naga, termasuk juga mengenai teknik pengemasan dan pemasarannya. Berdasarkan hasil yang diperoleh dapat disimpulkan bahwa diversifikasi pengolahan buah naga merupakan salah satu cara yang sangat efektif untuk meningkatkan pendapatan masyarakat di daerah Nagari Simpang Sugiran. Buah naga dapat diolah menjadi berbagai produk olahan dengan menggunakan teknologi yang sederhana, dan dapat dilakukan sebagai industri rumah tangga. Berdasarkan tingkat penerimaan konsumen, olahan buah naga sangat disukai karena rasa enak, renyah dan gurih, warnanya menarik dengan aroma yang khas. Kegiatan pengabdian masyarakat ini mampu menjadi motivasi dan mendorong jiwa kewirausahaan Kelompok Tani Sejahtera Jorong Boncah Nagari Simpang Sugiran Kecamatan Guguak, Kabupaten Lima Puluh Kota. Produk yang dihasilkan bisa dijadikan salah satu peluang usaha. Langkah lanjutan, bahwa produk akan didaftarkan ke Dinas Kesehatan setempat untuk mendapatkan sertifikat P-IRT, dan pengurusan sertifikat Halal.

\section{DAFTAR PUSTAKA}

Basri H, dkk, 2013, Aklimatisasi Bibit Tanaman Buah Naga (Hylocereus Undatus) pada Tingkat Naungan Berbeda E-J. Agrotekbis 1 (4).

Kotler P, Armstrong G. 2008. Prinsip-prinsip Pemasaran. Jilid 1. Jakarta (ID): Erlangga.

Kotler dan Keller 2009. Manajemen Pemasaran. Jilid I. Edisi ke 13. Jakarta : Erlangga.

Rangkuti, Freddy. 2010. Analisis SWOT Teknik Membedah Kasus Bisnis. Jakarta: PT. Gramedia Pustaka Utama.

Syarief, R. 1990. Pengemasan dan Perlindungan Mutu Bahan Pangan. PAU Pangan dan Gizi IPB. Bogor. 